\title{
Mg K-Edge XAFS Study of Silica-Magnesia Systems
}

\author{
H. Yoshida, T. Yoshida*, T. Tanaka*, T. Funabiki*, S. Yoshida*, T. Abe, K. Kimura and T. Hattori \\ Department of Applied Chemistry, School of Engineering, Nagoya University, Nagoya 464-01, Japan \\ * Department of Molecular Engineering, School of Engineering, Kyoto University, Kyoto 606-01, Japan
}

\begin{abstract}
Mg K-edge XAFS study was carried out to clarify the local structure of silica-magnesia systems prepared in four ways; by impregnation of silica with an aqueous solution of magnesium nitrate or with a methanol solution of magnesium methoxide, and by sol-gel method with tetraethyl orthosilicate and magnesium solutions mentioned above. It is clarified that the preparation method decides the structure of $\mathrm{Mg}$ species respectively; (i) $\mathrm{MgO}$ particle on silica, (ii) dispersed $\mathrm{Mg}$ species on silica surface, (iii) dispersed $\mathrm{Mg}$ tetrahedral species in silica bulk.
\end{abstract}

\section{INTRODUCTION}

Silica-magnesia system is known as an acid-base bifunctional catalyst which promotes dehydration and dehydrogenation of alcohols and so on [1-3]. However, the function of the catalysts was not controlled completely, since the acid-base properties are affected by various factors, e.g. preparation method, composition and treatment [4-6]. In order to control the function sophisticatedly, it is important to know the status of component ion, especially the local structure of $\mathrm{Mg}$ ion; e.g. $\mathrm{Mg}$ ion in magnesium oxides is octahedrally coordinated, while it is believed that $\mathrm{Mg}$ ion located in silica matrix is tetrahedral coordinated $[4,5,7,8]$. In this study Mg K-edge XAFS was employed to obtain information of the local structure of the Mg ions in silica-magnesia samples.

\section{EXPERIMENTAL}

Silica-magnesia samples were prepared in following four ways. $\mathrm{MgO}$ content of each sample was 15 mass $\%$ as standard. (I) Supported sample $\mathrm{MgO} / \mathrm{SiO}_{2}(\mathrm{~W})$ was prepared by impregnation of silica with an aqueous solution of $\mathrm{Mg}\left(\mathrm{NO}_{3}\right)_{2}$ followed by evaporation to dryness and calcination in air at $773 \mathrm{~K}$. Silica support was prepared from $\mathrm{Si}\left(\mathrm{OC}_{2} \mathrm{H}_{5}\right)_{4}$, ethanol and water by. sol-gel method [9]. (II) Another supported sample $\mathrm{MgO} / \mathrm{SiO}_{2}(\mathrm{M})$ was prepared in the same manner with a methanol solution of $\mathrm{Mg}\left(\mathrm{OCH}_{3}\right)_{2}$ instead of the aqueous solution. The solution was prepared by reaction of magnesium metal with refluxed

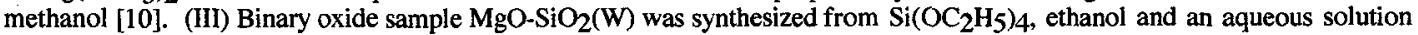
of $\mathrm{Mg}\left(\mathrm{NO}_{3}\right)_{2}$ by sol-gel method followed by drying and calcination. (IV) Another binary oxide sample $\mathrm{MgO}^{-\mathrm{SiO}_{2}}(\mathrm{M})$ was synthesized in the same way with a methanol solution of $\mathrm{Mg}\left(\mathrm{OCH}_{3}\right)_{2}$ instead of the aqueous solution. In addition to these four samples, a reference catalyst [11] JRC-SM-1 (MgO contents was 29 mass\%, the Catalysis Society of Japan) was also employed, which was synthesized hydrothermally from $\mathrm{MgO}$ and $\mathrm{SiO}_{2}$. X-ray absorption experiments were carried out on the BL-7A at UVSOR, Institute for Molecular Science, Okazaki, Japan [12], with a ring energy $750 \mathrm{MeV}$ and stored current of 80$200 \mathrm{~mA}$. Spectra were recorded at room temperature, using a beryl two-crystal monochromator in a total electron yield mode. The sample was mixed with active carbon in dry hexane and was put on the first photocathode made of $\mathrm{Cu}-\mathrm{Be}$ of the electron multiplier.

\section{RESULTS AND DISCUSSION}

Figure 1 shows XANES spectra of the silica-magnesia samples a) - e) and reference compounds f) - k). Reference spectra f) k) seem to be dominantly composed of three peaks, though the energy position, intensity and sharpness are different from each other. The spectra of the prepared silica-magnesia samples a) - d) are classified into three types, indicating that the local structures around $\mathrm{Mg}$ atom are obviously distinguishable.

The XANES of $\mathrm{MgO}_{\mathrm{SiO}}(\mathrm{M})$ b) is obviously identical with that of $\mathrm{MgO}$ ) of typical rock salt structure, indicating $\mathrm{Mg}$ ion exists as $\mathrm{MgO}$ particle, i.e. the $\mathrm{Mg}$ ion is octahedrally surrounded by 6-oxygen atoms. It has been also reported that $\mathrm{MgO}$ small particles on silica [13] and zeolite [14] were produced in this method. $\mathrm{Mg}\left(\mathrm{OCH}_{3}\right)_{2}$ easily reacts with water. In methanol solution, $\mathrm{Mg}\left(\mathrm{OCH}_{3}\right)_{2}$ reacts with surface hydroxyl groups on silica and/or reacts with $\mathrm{H}_{2} \mathrm{O}$ and $\mathrm{Mg}(\mathrm{OCH})_{2}$ molecules in methanol. Each reactions leads to dispersed $\mathrm{Mg}$ species and $\mathrm{MgO}$ particle, respectively. Since $\mathrm{MgO}$ particle was produced in this sample, the latter reaction would be dominant;

$$
2 \mathrm{Mg}\left(\mathrm{OCH}_{3}\right)_{2}+\mathrm{H}_{2} \mathrm{O} \rightarrow \mathrm{Mg}\left(\mathrm{OCH}_{3}\right)-\mathrm{O}-\mathrm{Mg}\left(\mathrm{OCH}_{3}\right)+2 \mathrm{CH}_{3} \mathrm{OH} \text {. }
$$


The XANES of $\mathrm{MgO}_{2} \mathrm{SiO}_{2}(\mathrm{M}) \mathrm{d}$ ) is essentially identical to that of JRC-SM-1 e) and a magnesium silicate, $\mathrm{Mg}_{2} \mathrm{Si}_{3} \mathrm{O}_{8}$ i). Sol-gel method and hydrothermal synthesis are known to be suitable for preparing binary oxide whose components are well mixed at an atomic level, i.e., $\mathrm{Mg}$ ions would be completely in the silica tetrahedral matrix. Therefore this spectra would be assigned to the tetrahedrally coordinated $\mathrm{Mg}$ ion. Through hydrolysis and condensation between $\mathrm{Mg}\left(\mathrm{OCH}_{3}\right)_{2}$ and $\mathrm{Si}_{(}\left(\mathrm{OC}_{2} \mathrm{H}_{5}\right)_{4}$, $\mathrm{Mg}-\mathrm{O}-\mathrm{Si}$ network would be constructed, and high dispersion of $\mathrm{Mg}$ ion in silica matrix would be achieved;

$\mathrm{Mg}(\mathrm{OR})_{2}+\mathrm{Si}(\mathrm{OR})_{4}+\mathrm{H}_{2} \mathrm{O} \rightarrow \mathrm{Mg}(\mathrm{OR})-\mathrm{O}-\mathrm{Si}(\mathrm{OR})_{3}+2 \mathrm{ROH}\left(\mathrm{R}=\mathrm{H}, \mathrm{CH}_{3}, \mathrm{C}_{2} \mathrm{H}_{5}\right)$.

$\mathrm{MgO} / \mathrm{SiO}_{2}(\mathrm{~W})$ a) shows another type of XANES which has twin broad peaks at 1310 and $1315 \mathrm{eV}$. There are no identical spectrum of the references. Generally in the supported catalysts, metal oxide loaded is classified into alternative structures; particle or dispersed species on the surface. The XANES of $\mathrm{MgO} / \mathrm{SiO}_{2}(\mathrm{~W})$ is clearly different from that of the former, therefore this is assigned to the latter species. Since the species on the silica surface would be affected by silica matrix structurally or electronically, we tentatively propose that it is surface tetrahedral species. The difference between the spectra a) and d) would be explained by the location of $\mathrm{Mg}$ species; on the surface or in the bulk. This sample $\mathrm{MgO} / \mathrm{SiO}_{2}(\mathrm{~W})$ a) was prepared by using aqueous solution of $\mathrm{Mg}\left(\mathrm{NO}_{3}\right)_{2}$. A similar spectrum has reported for $\mathrm{Mg}$ /zeolite prepared in the same manner [14]. Under the preparation, it is suggested that $\mathrm{Mg}$ ion in aqueous solution adsorbed on the negative charge points of silica surface so that $\mathrm{Mg}$ oxide species produced are dispersed and strongly affected by silica surface.

The sample $\mathrm{MgO} \mathrm{SiO}_{2}(\mathrm{~W})$ were also prepared by using aqueous solution of $\mathrm{Mg}\left(\mathrm{NO}_{3}\right)_{2}$. The spectrum c) is identical to that of $\mathrm{MgO} / \mathrm{SiO}_{2}(\mathrm{~W})$ a), suggesting that the magnesium species are mainly located on the surface of silica. While $\mathrm{Mg}$ ion exists as a hydrate cation in aqueous solution, silica-gel network was constructed through the hydrolysis and condensation,

$$
2 \mathrm{Si}(\mathrm{OR})_{4}+\mathrm{H}_{2} \mathrm{O} \rightarrow \underset{\left(\mathrm{R}=\mathrm{H}, \mathrm{C}_{2} \mathrm{H}_{5}\right) .}{\mathrm{Si}(\mathrm{OR})_{3}-\mathrm{O}-\mathrm{Si}(\mathrm{ROH}}
$$

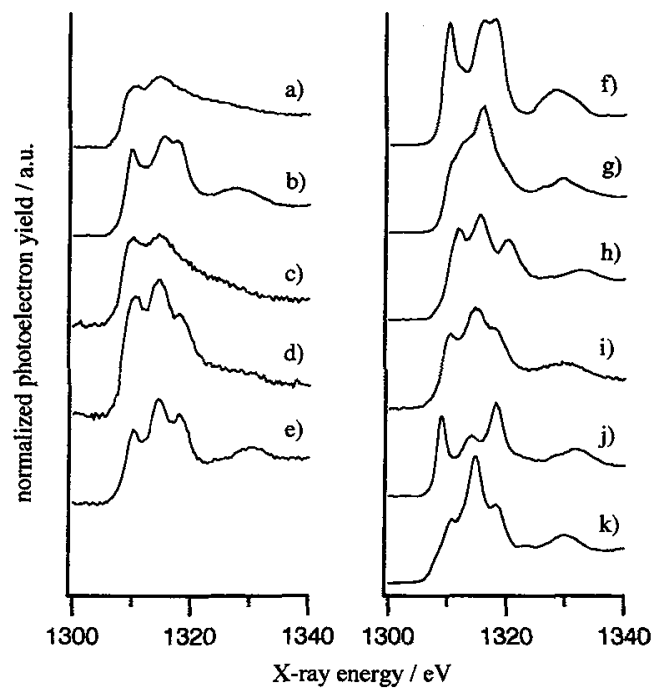

Figure 1 XANES spectra of the silica-magnesia samples and reference compounds. a) $\mathrm{MgO} / \mathrm{SiO}_{2}(\mathrm{~W})$, b) $\mathrm{MgO} / \mathrm{SiO}_{2}(\mathrm{M})$, c) $\mathrm{MgO}-\mathrm{SiO}_{2}(\mathrm{~W})$, d) $\mathrm{MgO}-\mathrm{SiO} 2(\mathrm{M})$, e) JRC-SM-1, f) $\mathrm{MgO}$, g) $\mathrm{Mg}_{2} \mathrm{SiO}_{4}$ [13], h) $\mathrm{MgSiO}_{3}$ [13], i) $\mathrm{Mg}_{2} \mathrm{Si}_{3} \mathrm{O}_{8}$, j) $\mathrm{MgAl}_{2} \mathrm{O}_{4}, \mathrm{k}$ ) $\mathrm{Mg}(\mathrm{OH})_{2}$.

ion would not react with $\mathrm{Si}\left(\mathrm{OC}_{2} \mathrm{H}_{5}\right)_{4}$ but only adsorb silica gel, resulting in the dispersed $\mathrm{Mg}$ oxide species like that of $\mathrm{MgO} / \mathrm{SiO}_{2}(\mathrm{~W})$.

In conclusion, it is clarified that three types of magnesium oxide species in silica-magnesia systems are respectively prepared by each suitable method; (i) $\mathrm{MgO}$ particle on silica, where $\mathrm{Mg}$ ion is located octahedral site, (ii) dispersed magnesium oxide species on the silica surface, which is interacted with surface silica matrix, (iii) dispersed Mg species in the silica matrix, which is tetrahedral.

\section{Acknowledgements}

X-ray absorption experiments were approved by the Joint Studies Program (1991-1995) of UVSOR of the Institute for Molecular Science. HY was supported by a grant in aid from the JSPS for Japanese Junior Scientists.

\section{References}

[1] Niiyama H. and Echigoya E., Bull. Chem. Soc. Jpn. 44 (1971) 1739-1742.

[2] Niiyama H., Morii S. and Echigoya E., Bull. Chem. Soc. Jpn. 45 (1972) 655-659.

[3] Niiyama H. and Echigoya E., Bull. Chem. Soc. Jpn. 45 (1972) 938-939.

[4] Briend-Fraure M., Kermarec M. and Delafosse D., Bull. Soc. Chim. France 11 (1974) 2393 - 2398.

[5] Kermarec M., Briend-Faure M. and Delafosse D., J. Chem. Soc. Faraday Trans. 170 (1974) 2180-2188.

[6] Tanabe K., Misono M., Ono Y. and Hattori H., New Solid Acids and Bases (Elsevier, Amsterdam, 1989) pp. $108-128$.

[7] Dzis'ko V. A., Borisova M. S., Karachiev L. G., Makarov A. D., Kotsapenko N. C., Zusman R. I. and Chrupin L. A., Kinetika $i$ Kataliz 6 (1965) 1033.

[8] Yoshida H., Tanaka T., Satauma A., Hattori T., Funabiki T. and Yoshida S., Chem. Commun. (1996) 1153-1154.

[9] Yoshida S., Matsuzaki T., Kashiwazaki T., Mori K. and Tarama K., Bull. Chem. Soc. Jpn. 47 (1974) 1564-1567.

[10] Tanaka T., Yoshida H., Nakatsuka K., Funabiki T. and Yoshida S., J.Chem.Soc.Faraday Trans. 88 (1992) 2297-2298.

[11] Uchijima T., "Activities in the First Decade of the Committee on Reference Catalyst, the Catalysis Society of Japan", the First Tokyo Conference on Advanced Catalytic Science and Technology, Tokyo 1-5 July 1990, S. Yoshida, N. Takezawa and T. Ono Eds. (Kodansha, Tokyo, VCH, Weinheim, 1991) pp. 393-398.

[12] Murata T., Matsukawa T., Naoe S., Horigome T., Matsudo O. and Watanabe M., Rev. Sci. Instrum. 63 (1992) $1309-1312$.

[13] Yoshida H., Tanaka T., Nakatsuka K., Funabiki T. and Yoshida S., Stud. Surf. Sci. Catal. 90 (1994) 473-478.

[14] Tsuji H., Yagi F., Hattori H. and Kita H., "Characterization of basic sites on fine particles of alkali and alkaline earth metal oxides in zeolites", 10th Intern. Congr. Catal., Budapest 19-24 July 1992, L. Guczi, F. Solymosi and P. Tetenyi Eds. (Akademiai Kiado, Budapest, 1993) pp. 1171-1183. 